\title{
Bibliometric patterns and indicators of research collaboration of Egyptian health scientists: $1980-2014$
}

\author{
Ibrahim Shehatta ${ }^{1,2}$ and Khalid Mahmood ${ }^{3}$ \\ ${ }^{1}$ Ranking Unit, Deanship of Quality and Academic Accreditation, \\ University of Dammam, SAUDI ARABIA \\ ${ }^{2}$ Chemistry Department, Faculty of Science, \\ Mansoura University, EGYPT \\ ${ }^{3}$ Department of Information Management, \\ University of the Punjab, Lahore, PAKISTAN \\ e-mail: isshehata@uod.edu.sa (corresponding author); khalid.im@pu.edu.pk
}

\begin{abstract}
The present study examines Egyptian publications and research collaboration in health sciences using Thomson Reuters InCites ${ }^{T M}$ over the period of 1980-2014. Egypt, in clinical, pre-clinical and health, is ranked 44 among all countries according to the Web of Science documents (quantity) and total citations (quality). It is ranked at 40 and 55 respectively for international collaboration and the total number of highly cited papers. The total publications of Egyptian scientists in health sciences were 31 382, of which 27693 articles were multi-authored, indicating a co-authorship ratio of 88 percent. It reveals that Egyptian scientists have a great tendency to collaborate. The collaborated papers show a greater citation impact, category normalized citation impact, and journal normalized citation impact and $h$-index compared to single authored papers. This reveals that the visibility and impact of co-authored papers are higher than that of single authored ones, as well as the visibility and impact of internationally co-authored publications are higher than the single authored or domestic papers. Egyptian scientists, in clinical, pre-clinical and health, had joint publications with their colleagues in 166 countries during the period under study. These countries were grouped according to geographic position, scientific capacity and economic development rate. The results show that Egypt's main partners were USA, Saudi Arabia, Germany, England and Japan. In addition, Egyptian researchers mostly co-published with colleagues in Europe, scientifically advanced countries and high income countries. The findings could inform policy makers to develop research policies aiming to foster and support collaborations at all levels -researchers, institutions and countries.
\end{abstract}

Keywords: Bibliometrics; Research collaboration; Research productivity and impact; Health sciences; Egypt

\section{INTRODUCTION}

Collaboration among researchers, especially at international level, has a positive influence on the impact of research. It has extensively been studied using bibliometric analysis (Abramo et al. 2011; Adams 2013; Adams et al. 2005; Adams et al. 2014; Bordons et al. 
2013; Chuang et al. 2011; Durando et al. 2007; Ganzi and Didegah 2011; Ganzi et al. 2012; Glänzel 2001; Glänzel and De Lange 2002; Glänzel and Schubert 2004; Gonzalez-Alcaide et al. 2010; Hanna-Mari et al. 2014). Collaboration is of utmost importance for authors, departments, institutions and countries. It is of special interest for developing countries because research collaboration is considered as an indicator for the quality of participating scientists or research groups. Also, it is an effective way to close gap between developing and developed countries as well as to get access to the advanced scientific knowledge and recent technologies. Various benefits and merits of research collaboration were recognized such as sharing and transferring knowledge; developing new ideas; problem solving; stimulating innovation and creativity; connecting researchers to a wider scientific network; improving the visibility and recognition of scientists and articles; utilizing expensive equipment, acquiring expertise; sharing resources, enhancing quality and quantity of publications; raising academic output and citation impact of authors, institutions and countries, especially the developing countries; breaking down the barriers and obstacles between institutions and industries (De Filippo et al. 2009; Guerrero-Bote et al. 2013).

Nowadays, there is greater collaboration across countries in various disciplines of clinical, pre-clinical and health. An example is the global response to emerging infectious diseases aiming to prevent and control these diseases where research groups collaborate in an integrated manner that includes vector control, vaccination programmes, improved therapy strategies, diagnostic tools and surveillance, public awareness, capacity building and improvement of infrastructure in endemic region (Ahmed et al. 2009). It is usually done using various successful approaches such as developing capacity building, building communication networks, enhancing resources and research collaboration (Liu, Mu and Xie 2016; Richet et al. 2001).

This growing trend and positive influence of collaboration stimulated us to examine the research performance and collaboration of Egyptian researchers in health sciences. This evaluation of research performance is important to frame policies to promote research. The discipline of health sciences is chosen as a case study of Egyptian research due to several reasons. Most of the diseases are non-boundary diseases such as AIDS/HIV and severe acute respiratory syndrome (SARS). These diseases are universal in nature and need to be studied across nations in the attempt to determine differences in genetic, cultural beliefs and attitudes, and personal responses to different treatments (Freshwater et al. 2006)

Bibliometric indicators have been extensively applied to provide insights into the global landscape of science in the century of knowledge-based economy (21st century). These indicators are considered most valuable and common approaches to assess research performance, as well as domestic and international collaboration (Bordons et al. 2013; Bornmann and Leydesdorff 2013; Gazni and Didegah 2011; Gazni, Sugimoto and Didegah 2012; Lancho-Barrantes et al. 2013; Leydesdorff et al. 2013; Mostafavi and Bazrafshan 2014; Patel et al. 2011; Persson et al. 2004; Schmoch and Schubert 2008; Shrivats and Bhattacharya 2014; Waast and Rossi 2010; Wagner and Leydesdorff 2005; Wang et al. 2011; Yu et al. 2014).

A review of the literature has revealed that there are very few publications on research productivity of Egyptian bio-medical researchers. Helal et al. (2014) studied the publication productivity of medical research of the Faculty of Medicine, Mansoura University, Egypt using the PubMed database. They found that there was an increase in the publication rate over period covered. The high-producing subjects were urology and nephrology. The 
median number of authors participated in the researches was four. The median of the impact factor was 1.99. The Egyptian biomedical publications in PubMed over the period 1996-2005 were investigated by Afifi (2007). The results show that there was an overall increase in the share of Egyptian publications in PubMed during this time span. The average number of authors per publication also increased. The coverage period was limited to only 10 years. Using the journal impact factor (JIF), a quantitative and qualitative assessment of biomedical publication of Iran, Pakistan and Egypt were undertaken by Ghaleh et al. (2004). There was an 11 percent increase in the impact factor of Egyptian publications between 1992 and 2002. A comparison between Egypt and the world publications in cancer and biomedical have been studied by Zeeneldin et al. (2012). Egyptian publications contributed about 0.13 percent to their world counterparts. This contribution increased from year to year between 1991 and 2010. The publication productivity of medicine \& pharmacy schools in four Arab universities (Saudi Arabia, Egypt, Sudan and Jordan) were compared using Web of Science (WoS) database over the period 2005-2010 by Maghrabi (2013). Colleges of medicine and pharmacy had a contribution of about 25 percent of the overall university publications for all universities. Colleges of medicine had higher percent share than colleges of pharmacy in university publications. The focus of almost all studies reviewed here was productivity rather than collaboration of Egyptian authors with the faculty and staff of other national and international organizations. There was a need to study publication patterns of Egyptian bio-medical researchers with a focus on an important bibliometric aspect, i.e., collaboration among authors.

To the best of our knowledge, this is the first effort of an in-depth analysis of Egyptian research performance and to describe the co-authorship and collaborations at institutional and country levels. In the present study, we have analyzed the development of Egyptian publications and collaborations in health sciences over a 35 years period (1980-2014). The focus of this paper is research collaboration and the indicators that are used to measure collaborative impact. The objective is to reach a comprehensive overview of Egyptian research and collaboration activities, aiming to describe the production and trend of scientific publications, identify the collaboration patterns of Egyptian researchers and their various analysis levels (author, journal, institution and country), define the top collaborating countries, the most collaborative national and international institutions, as well as the motivating factors of international collaboration of Egypt. The findings will inform the policymakers at all levels (country, institution, funding agencies, etc.) in strategic planning, fund allocation, benchmarking and achieving objectives as well as missions.

\section{RESEARCH QUESTIONS}

Bibliometric data over a 35-year period (1980-2014) for Egyptian scholars in clinical, preclinical and health, is used to address the following research questions:

1. What is the research profile of Egyptian researchers?

2. What is the collaboration rate among Egyptian researchers?

3. Are there any differences in bibliometric indicators of Egyptian papers published through international collaboration as compared to papers published through domestic or without collaboration?

4. What are the most active Egyptian institutions in total publications and in collaborating publications?

5. What are the top research partners (countries and institutions) of Egypt? 
6. How is Egypt's scientific collaboration with the six continents and countries categorized as high, upper-middle, low-middle and low income, as well as with countries categorized as scientifically advanced, proficient, developing and lagging?

7. At what level does Egypt collaborate with high, medium and low R\&D investing countries?

8. Is the magnitude of international collaboration a predictive indicator of research quantity (publications) and quality (citations)?

\section{MATERIALS AND METHOD}

The scope of the present study is the Egyptian medical and health research collaboration during a 35-year period (1980-2014). Bibliometric indicators of Egypt research publications were retrieved for the 35 years as well as for the seven five-year periods, i.e., 1980-1984, 1985-1989, 1990-1994, 1995-1999, 2000-2004, 2005-2009, 2010-2014. The data and metrics for the present study were retrieved on 16 September 2015 using Thomson Reuters' InCites ${ }^{\mathrm{TM}}$ tool. There were $\geq 48$ million Web of Science (WoS ${ }^{\mathrm{TM}}$ ) documents over the period 1980-2014, out of which $\geq 14$ million WoS ${ }^{\mathrm{TM}}$ documents were in clinical, preclinical and health category according to the Global Institutional Profile Project, GIPP. The InCites $^{\mathrm{TM}}$ is a web-based research analytics solution tool allowing benchmarking of research performance of scientists, institutions and countries. InCites ${ }^{\mathrm{TM}}$ has many unique features such as: using a long duration period (1980-2014); providing publications and citation metrics as well as normalized citation impact values; comparing with global baseline; containing various research area schemas; easy downloading of various bibliometric indicators in Microsoft Excel format; etc. Each document in WoS ${ }^{\mathrm{TM}}$ is assigned to one of 252 subject areas, according to the published journals. The journal impact factor (JIF), category, quartile and rank are taken from Journal Citation Reports (JCR) database. The JCR is an effective tool to evaluate World's leading research journals. T-test was used to see difference in the citation impact of papers with and without collaboration.

\section{RESULTS AND DISCUSSION}

\section{Research Profile of Egypt in Various Schemas}

Through using various subject categories (schemas) and benchmarking, publications and citations data become meaningful numbers and actionable knowledge (InCites ${ }^{\mathrm{TM}}$ 2014). Therefore, the present work studied 31382 articles indexed in InCites ${ }^{\mathrm{TM}}$ database over the period of 1980-2014 using four different schemas, namely GIPP (Global Institutional Profile Project), ESI (Essential Sciences Indicators), WoS (Web of Sciences) and OECD (Organization for Economic Co-operation and Development). The very broad categorization notably GIPP consists of six broad disciplines that covers all research fields. Whereas, the broad categorization namely ESI includes 22 subject areas in science and social sciences only. The WoS is the narrowest categorization that has 252 subject categories in sciences, social sciences, arts and humanities. The fourth schema is OECD which comprises six broad subject fields. A concordance tables between the OECD or GIPP and the WoS subject categories are available (InCites ${ }^{\mathrm{TM}}$ 2014).

Based on GIPP, there are a total of 31382 Egyptian scientific publications in 1980-2014 in the broad category of "clinical, pre-clinical and health", which accounts for 24.9 percent of 
the total Egyptian publications in the six broad fields. These publications, as covered by InCites ${ }^{\mathrm{TM}}$, were analyzed in detail.

Table 1: Distribution of Papers According to Different Subject Schemas

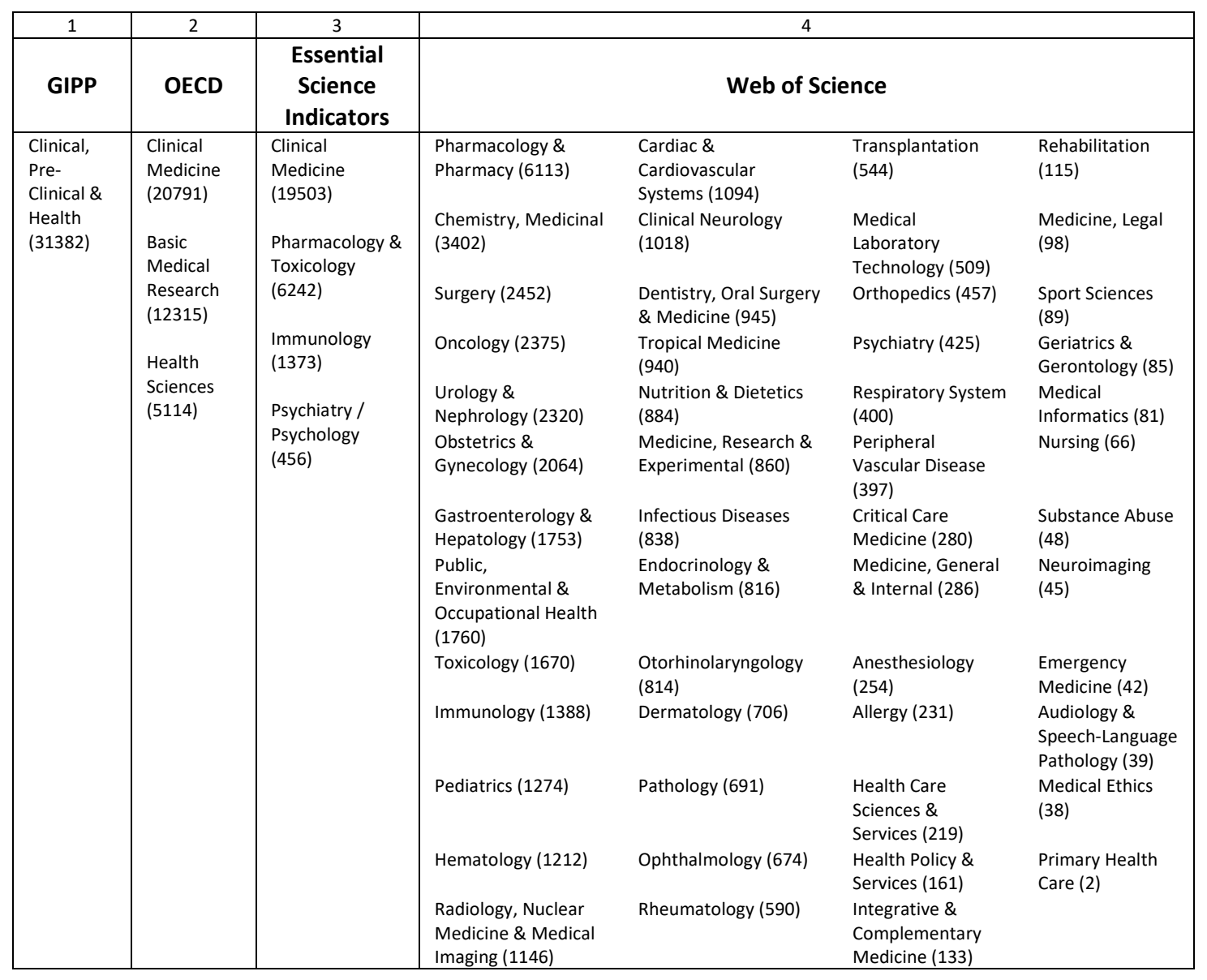

Note: The sum may not be exact. A paper may be counted in various subject areas.

\section{Research Trend and Collaboration}

The total number of Egyptian articles (31 382) in clinical, pre-clinical \& health, over the period 1980-2014, is equivalent to 0.22 percent of the world output during the same period. The Egyptian citation impact is 7.56, whereas the citation impact of the world baseline is 12.95. Moreover, the Egypt's international collaboration represents 0.83 percent of the global baseline's international collaboration. The publications of Egyptian authors in clinical, pre-clinical and health have been growing considerably since 1980 . The number of papers increased with an average annual growth rate of 30.7 percent. The growth of publications in the last five years $(2010-2014)$ accounted for 43.9 percent of the total publications since the first 5-years period $(1980-2014)$ as shown in Table 2 and Figure 1. In clinical, pre-clinical and health, Egypt is ranked 44 among all countries according to the WoS ${ }^{\mathrm{TM}}$ documents (quantity) and total citations (quality). Whereas Egypt is ranked 40th and 55th with respect to international collaboration and the total number of highly cited papers, respectively. 
Shehatta, I. \& Mahmood, $K$.

Table 2: Number and Share of Collaborated Papers over Seven Periods of 5-years (1980 - 2014)

\begin{tabular}{|c|c|c|c|c|c|c|c|c|c|c|}
\hline \multirow{3}{*}{$\begin{array}{l}\text { Publication } \\
\text { period }\end{array}$} & \multirow{3}{*}{$\begin{array}{c}\text { Total } \\
\text { papers }\end{array}$} & & & \multicolumn{7}{|c|}{ Collaboration } \\
\hline & & \multicolumn{2}{|c|}{ No collaboration } & \multicolumn{2}{|c|}{ Total papers } & \multicolumn{2}{|c|}{ Domestic (D) } & \multicolumn{2}{|c|}{ International (I) } & \multirow{2}{*}{$\begin{array}{c}\text { Proportion } \\
(D / I)\end{array}$} \\
\hline & & Number & Share & Number & Share & Number & Share & Number & Share & \\
\hline 1980-1984 & 1439 & 212 & 0.15 & 1227 & 0.85 & 918 & 0.64 & 309 & 0.21 & 2.97 \\
\hline 1985-1989 & 1409 & 159 & 0.11 & 1250 & 0.89 & 863 & 0.61 & 387 & 0.27 & 2.23 \\
\hline 1990-1994 & 1687 & 258 & 0.15 & 1429 & 0.85 & 844 & 0.50 & 585 & 0.35 & 1.44 \\
\hline 1995-1999 & 2566 & 446 & 0.17 & 2120 & 0.83 & 1186 & 0.46 & 934 & 0.36 & 1.27 \\
\hline 2000-2004 & 3571 & 554 & 0.16 & 3017 & 0.84 & 1700 & 0.48 & 1317 & 0.37 & 1.29 \\
\hline 2005-2009 & 6939 & 803 & 0.12 & 6136 & 0.88 & 3455 & 0.50 & 2681 & 0.39 & 1.29 \\
\hline 2010-2014 & 13771 & 1257 & 0.09 & 12514 & 0.91 & 6674 & 0.48 & 5840 & 0.42 & 1.14 \\
\hline $1980-2014$ & 31382 & 3689 & 0.12 & 27693 & 0.88 & 15640 & 0.50 & 12053 & 0.38 & 1.30 \\
\hline
\end{tabular}

Note: Share refers to a fraction/part of 1.00

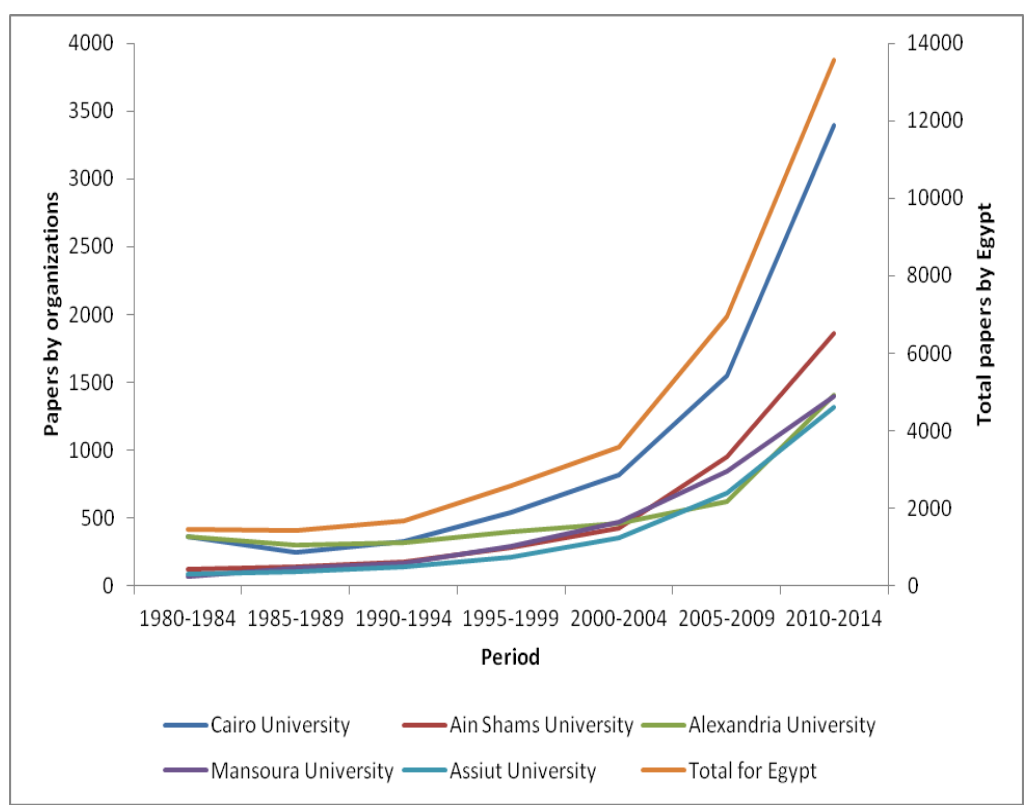

Figure 1: Trend in Number of Web of Science Papers by Top 5 Organizations in Comparison with Total Papers by Egypt

Table 2 and Figure 2 show the number and share of collaborated papers over seven periods of 5-years and 35-years period (1980 - 2014). A total of 1227 papers had coauthors during the period 1980-1984, which increased annually until it reached the maximum value (12 514 papers) during the period 2010-2014. It shows a 10-fold increase over 35 years. Internationally, the co-authored papers increased from 309 in 1980-1984 to 5840 papers in 2010-2014. It accounts for 19 times increase over the same period (35 years). Also, the share of international co-authored papers in the total papers increased from 0.21 (1980-1984) to 0.42 (2010-2014) indicating a double increase. 


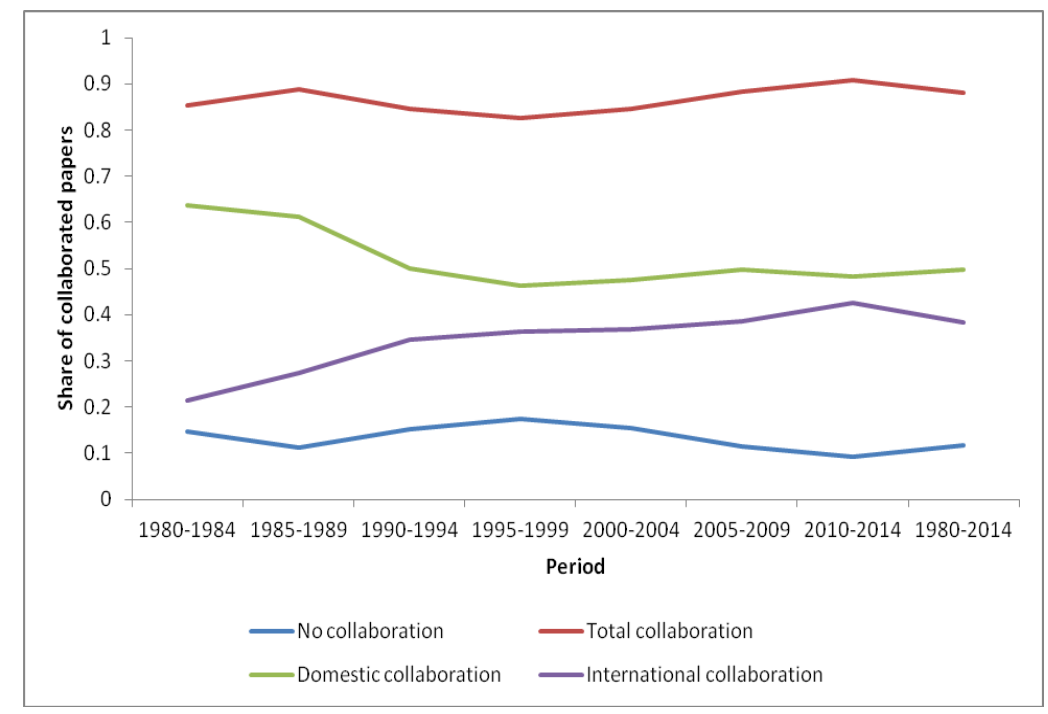

Figure 2: Share of Collaborated and Non-collaborated Papers

On the other hand, the domestic co-authored papers were 918 (1980-1984), which decreased a little to 863 and 844 during 1985-1989 and 1990-1994 respectively. After that, it increased over various periods until it reached the maximum value at 6674 papers during 2010-2014. It increased from 1980-1984 to 2010-2014 accounting for only seven times, which is less than the increase in international collaboration (16 times) during the same period. Moreover, the share of domestic collaborative papers decreased from 0.64 during 1980-1984 to 0.48 during 2010-2014 (Figure 2). In general, the share of domestic coauthored papers is higher than the international co-authored papers at each time interval. The proportion of domestic to international publications decreased from 2.97 in 1980-1984 to 1.14 in 2010-2014, with average proportion equals to 1.30 , i.e., the share of total domestic co-authored papers to total international co-authored articles during the 35 years was 1.3 to 1.0. But, one can expect that the share of international co-authored papers in the coming five years will be more than the domestic ones, if the same rate in continuously done.

As can be seen in Table 2, Egyptian researchers in clinical, pre-clinical and health produced more collaborative articles with local co-authors $(50 \%)$ than with co-authors from other countries (38\%). This is in accordance with the findings obtained for Egypt (all subject fields) over the period of 2007-2011 using the Science Citation Expanded (SCl-Expanded) database (Pouris and Ho 2014). Pouris and Ho revealed 57 percent domestic collaborative articles and 43 percent international collaborative articles. Also, the domestic collaboration has a high degree compared to international collaborations in medical fields (Thijs and Glanzel 2010). These findings are revealing a trend towards team work and intense collaborative activities of Egyptian researchers in health sciences.

\section{Distribution of Single and Multi-authored publications}

Table 3 shows the values of the patterns found in inter-researcher collaboration. Out of 31,382 only 3689 papers (11.76\%) were single authored, revealing a co-authorship ratio of 88.24 percent, as well as the great tendency to collaborate among Egyptian scientists in the field of clinical, pre-clinical and health. Also, the researchers had a great tendency to collaborate in various subject fields (share $\geq 0.76$ ). Multi-authored publications show a greater citation impact than single authored papers (Table 3). Articles published with 
collaboration, in most research area schemas had between 1.3 and 9.92 times citation impact than the papers with no collaboration. Gazni and Didegah (2011) showed that the average number of normalized citations by multi-authored Harvard University's publications was about two times (ranged between 0.99 and 3.99) more than those by a single author for 22 subject fields according to the ESI schema.

Table 3: Ratio of Citation Impact of Papers With and Without Collaboration over the Period $1980-2014$ (Results of independent samples $t$ test)

\begin{tabular}{|c|c|c|c|c|c|c|c|c|c|}
\hline \multirow[b]{2}{*}{ Disciplines } & \multicolumn{3}{|c|}{$\begin{array}{l}\text { Papers with no } \\
\text { collaboration }\end{array}$} & \multicolumn{3}{|c|}{ Papers with collaboration } & \multirow[b]{2}{*}{$\begin{array}{l}\mathrm{Cl}(\mathrm{M}) / \\
\mathrm{Clx}(\mathrm{S})\end{array}$} & \multirow[b]{2}{*}{$\mathrm{t}$} & \multirow[b]{2}{*}{ Sig. } \\
\hline & Total $\mathrm{N}$ & $\mathrm{N}$ & $\begin{array}{c}\text { Citation } \\
\text { Impact } \\
\mathrm{Cl}(\mathrm{s}) \\
\end{array}$ & $\mathrm{N}$ & Share & $\begin{array}{c}\text { Citation } \\
\text { Impact } \\
\mathrm{Cl}(\mathrm{M}) \\
\end{array}$ & & & \\
\hline \multicolumn{10}{|l|}{ GIPP } \\
\hline $\begin{array}{l}\text { Clinical, Pre-Clinical \& Health } \\
\text { OECD }\end{array}$ & 31382 & 3689 & 5.63 & 27693 & 0.88 & 7.82 & 1.39 & -7.121 & $.000 * *$ \\
\hline Clinical Medicine & 20791 & 2643 & 4.98 & 18148 & 0.87 & 7.36 & 1.48 & -6.407 & $.000 * *$ \\
\hline Basic Medical Research & 12315 & 1255 & 6.81 & 11060 & 0.90 & 8.73 & 1.28 & -4.007 & $.000 * *$ \\
\hline Health Sciences & 5114 & 561 & 5.91 & 4553 & 0.89 & 9.4 & 1.59 & -4.112 & $.000 * *$ \\
\hline \multicolumn{10}{|l|}{ Essential Science Indicators } \\
\hline Clinical Medicine & 19503 & 2324 & 5.18 & 17179 & 0.88 & 7.43 & 1.43 & -5.516 & $.000^{* *}$ \\
\hline Pharmacology \& Toxicology & 6242 & 641 & 8.16 & 5601 & 0.90 & 8.12 & 1.00 & .063 & .950 \\
\hline Immunology & 1373 & 73 & 3.50 & 1300 & 0.95 & 10.89 & 3.11 & -2.855 & $.004 * *$ \\
\hline Psychiatry / Psychology & 456 & 109 & 3.94 & 347 & 0.76 & 7.71 & 1.96 & -2.467 & $.014 *$ \\
\hline \multicolumn{10}{|l|}{ Web of Science } \\
\hline Pharmacology \& Pharmacy & 6113 & 623 & 8.32 & 5490 & 0.90 & 8.35 & 1.00 & -.056 & .955 \\
\hline Chemistry, Medicinal & 3402 & 283 & 8.57 & 3119 & 0.92 & 9.51 & 1.11 & -.968 & .333 \\
\hline Surgery & 2452 & 562 & 5.64 & 1890 & 0.77 & 7.66 & 1.36 & -3.039 & $.002 * *$ \\
\hline Oncology & 2375 & 152 & 2.57 & 2223 & 0.94 & 8.49 & 3.30 & -2.983 & $.003 * *$ \\
\hline Urology \& Nephrology & 2320 & 421 & 6.23 & 1899 & 0.82 & 9.57 & 1.54 & -2.992 & $.003 * *$ \\
\hline Obstetrics \& Gynecology & 2064 & 252 & 5.77 & 1812 & 0.88 & 8.47 & 1.47 & -2.216 & $.027^{*}$ \\
\hline $\begin{array}{l}\text { Public, Environmental \& } \\
\text { Occupational Health }\end{array}$ & 1760 & 194 & 4.87 & 1566 & 0.89 & 10.52 & 2.16 & -4.260 & $.000^{* *}$ \\
\hline $\begin{array}{l}\text { Gastroenterology \& } \\
\text { Hepatology }\end{array}$ & 1753 & 148 & 5.65 & 1605 & 0.92 & 5.63 & 1.00 & .013 & .989 \\
\hline Toxicology & 1670 & 215 & 7.49 & 1455 & 0.87 & 9.44 & 1.26 & -2.214 & $.027^{*}$ \\
\hline Immunology & 1388 & 82 & 4.21 & 1306 & 0.94 & 10.91 & 2.59 & -6.915 & $.000^{* *}$ \\
\hline Pediatrics & 1274 & 123 & 4.44 & 1151 & 0.90 & 6.06 & 1.36 & -1.115 & .265 \\
\hline Hematology & 1212 & 96 & 1.08 & 1116 & 0.92 & 3.73 & 3.45 & -3.450 & $.001^{* *}$ \\
\hline $\begin{array}{l}\text { Radiology, Nuclear Medicine \& } \\
\text { Medical Imaging }\end{array}$ & 1146 & 128 & 5.18 & 1018 & 0.89 & 7.59 & 1.47 & -1.274 & .203 \\
\hline $\begin{array}{l}\text { Cardiac \& Cardiovascular } \\
\text { Systems }\end{array}$ & 1094 & 94 & 1.66 & 1000 & 0.91 & 4.76 & 2.87 & -5.054 & $.000^{* *}$ \\
\hline Clinical Neurology & 1018 & 152 & 3.88 & 866 & 0.85 & 7.52 & 1.94 & -4.252 & $.000 * *$ \\
\hline $\begin{array}{l}\text { Dentistry, Oral Surgery \& } \\
\text { Medicine }\end{array}$ & 945 & 143 & 5.21 & 802 & 0.85 & 6.62 & 1.27 & -1.738 & .084 \\
\hline Tropical Medicine & 940 & 50 & 4.18 & 890 & 0.95 & 12.77 & 3.06 & -7.574 & $.000 * *$ \\
\hline Nutrition \& Dietetics & 884 & 123 & 11.82 & 761 & 0.86 & 8.31 & 0.70 & 2.157 & $.032 *$ \\
\hline $\begin{array}{l}\text { Medicine, Research \& } \\
\text { Experimental }\end{array}$ & 860 & 64 & 7.02 & 796 & 0.93 & 7.42 & 1.06 & -.147 & .883 \\
\hline Infectious Diseases & 838 & 42 & 4.12 & 796 & 0.95 & 13.2 & 3.20 & -4.975 & $.000 * *$ \\
\hline Endocrinology \& Metabolism & 816 & 70 & 7.71 & 746 & 0.91 & 7.11 & 0.92 & .296 & .767 \\
\hline Otorhinolaryngology & 814 & 153 & 7.93 & 661 & 0.81 & 7.69 & 0.97 & .224 & .823 \\
\hline Dermatology & 706 & 74 & 5.12 & 632 & 0.90 & 6.93 & 1.35 & -1.241 & .215 \\
\hline Pathology & 691 & 73 & 6.58 & 618 & 0.89 & 6.29 & 0.96 & .146 & .884 \\
\hline Ophthalmology & 674 & 92 & 5.41 & 582 & 0.86 & 10.3 & 1.90 & -4.063 & $.000 * *$ \\
\hline Rheumatology & 590 & 21 & 0.52 & 569 & 0.96 & 5.16 & 9.92 & -7.609 & $.000 * *$ \\
\hline Transplantation & 544 & 33 & 5.36 & 511 & 0.94 & 3.5 & 0.65 & 1.158 & .248 \\
\hline $\begin{array}{l}\text { Medical Laboratory } \\
\text { Technology }\end{array}$ & 509 & 31 & 3.71 & 478 & 0.94 & 6.01 & 1.62 & -1.041 & .298 \\
\hline
\end{tabular}

* Significant at $\mathrm{p}<.05$

$* *$ Significant at $p<.01$

In the very broad categorization schema (GIPP), the Egyptian collaboration had 1.4 times increase in citation impact as compared to single authored papers. In OECD schema, the ratio of citation impact of multiple authors and single authors is between 1.28 and 1.59 . In ESI schema, this ratio is between 1.43 and 3.11, except for pharmacology and toxicology, in which the ratio is 1.0 - showing no difference in citation impact between papers with or without collaboration. 
The results of t-test indicated that there was a significant difference between citation impact of collaborated and non-collaborated papers in various disciplines (Table 3), except for pharmacology and toxicology; pharmacology and pharmacy; chemistry; medicinal; gastroenterology and hepatology; medicine, research and experimental; endocrinology, metabolism; otorhinolaryngology; dermatology; pathology; transportation and medical laboratory technology in which the t-test results show no significant difference at $95 \%$ confidence level.

\section{Author Analysis}

Table 4 shows the distribution of papers in terms of number of authors. The highest proportion corresponds to the papers performed by $\geq 5$ authors (39.42\%), followed by four authors $(18.85 \%)$, three authors $(16.95 \%)$, two authors $(13.03 \%)$ and finally single author $(11.76 \%)$. The data show that a co-authorship index of $\geq 3.61$ authors per paper (collaborative level, CL). It is not surprising because in some fields such as medicine, it is usual to find a greater number of authors in each article (Ardanuy 2012). These findings are consistent with those by Gazni and Didegah (2011), where they found a significant positive correlation $\left(R^{2}=0.907\right.$, sig. $\left.=0.001\right)$ between the number of authors and the citations number in Harvard University's publications.

Bibliometric indicators are calculated (Table 4) as a function of the number of authors (1, 2, $3,4 \& \geq 5$ ). The articles published through collaboration show a greater citation impact, category normalized citation impact, journal normalized citation impact and h-index, than those of single authored articles. It reveals that the visibility and impact of co-authored papers are higher than that of single authored ones. Moreover, the proportion of collaborated papers, total citations, citation impact, category normalized citation impact ( $\mathrm{CNCl}$ ) and h-index increase with increasing the number of authors. It is interesting to note that the $\mathrm{CNCl}$ value increases with increasing the number of authors and only the papers with $\geq 5$ authors have $\mathrm{CNCl}$ value close to 1 (World average). Also, the percentages of uncited papers are low for collaborated papers compared to that for single author. These results confirm that bibliometric indicators improved by collaboration as well as with the number of authors.

Table 4: Distribution of Papers According to the Number of Authors over the Period $1980-2014$

\begin{tabular}{lccccc}
\hline \hline & \multicolumn{5}{c}{ Number of authors } \\
\cline { 2 - 6 } \multicolumn{1}{c}{ Indicator } & 1 & 2 & 3 & 4 & $\geq 5$ \\
\hline Number of Web of Science papers & 3689 & 4088 & 5319 & 5914 & 12372 \\
\% of total papers & 11.76 & 13.03 & 16.95 & 18.85 & 39.42 \\
\% of collaborated papers & 0 & 14.76 & 19.21 & 21.36 & 44.68 \\
\% of uncited papers & 41.42 & 37.52 & 36.38 & 37.76 & 35.77 \\
Total citations & 20771 & 25188 & 34115 & 39754 & 117456 \\
Citation impact & 5.63 & 6.16 & 6.14 & 6.72 & 9.49 \\
Category Normalized Citation Impact & 0.39 & 0.50 & 0.54 & 0.54 & 0.95 \\
Journal Normalized Citation Impact & 0.65 & 0.89 & 0.83 & 0.79 & 0.91 \\
h-index & 49 & 51 & 57 & 62 & 102 \\
\hline \hline
\end{tabular}


The average number of authors per paper over 1980-2014 is examined. As shown in Figure 3 , this average has increased from 3.18 authors per paper in 1980-1984 to 3.73 authors per paper in 2010-2014, indicating that the proportion of co-authored publications was increasing over time, i.e., there is a noticeable upward trend of scientific collaboration among Egyptian researchers. These values are comparable with the results obtained (3.34.1 author per paper) for the world publications over the period $2000-2009$ (Gazni Sugimoto and Didegah 2012).

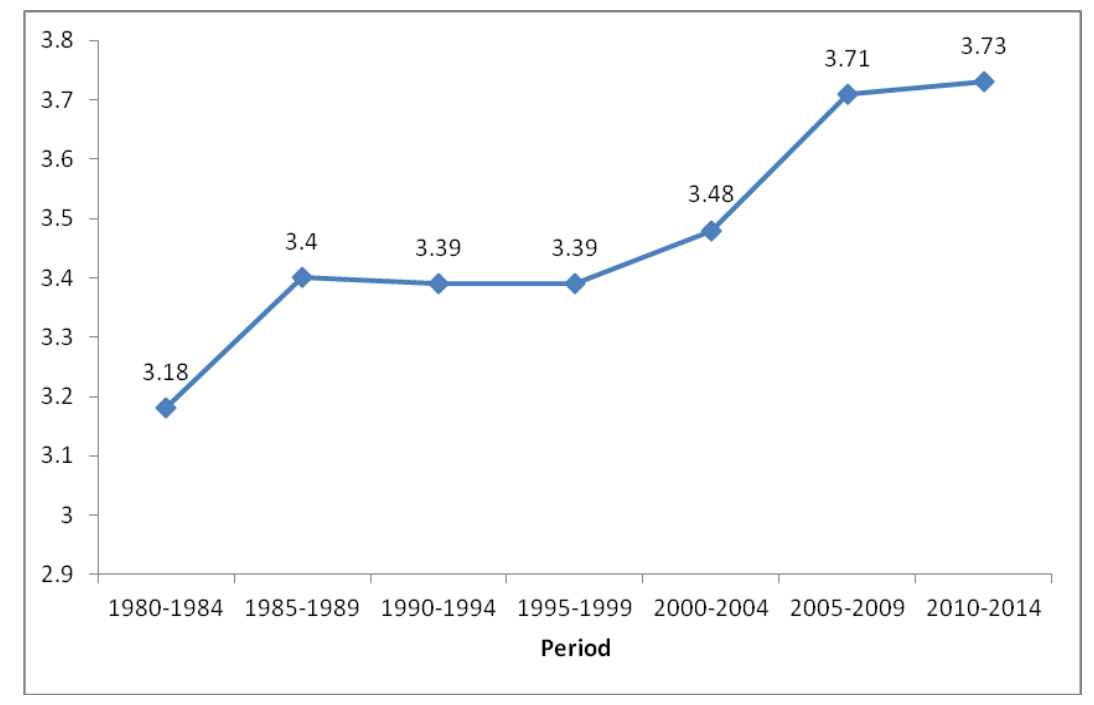

Figure 3: Number of Authors per Paper ( $N=31382)$

\section{Country Analysis}

\section{a) Collaborating countries with Egypt}

Egyptian medical scientists had joint publications with their colleagues in 166 countries during the period 1980-2014. In 1980-1984, the number of collaborating countries was 51 (total 309 papers, average paper per country $=6.06$ ), which increased regularly to reach 154 (total 5840 papers, average paper per country $=37.92$ ) in 2010-2014. In fact, the number of collaborating countries increased more than 3 times, whereas the total collaborating papers increased more than 6 times during the examined period. The total international publications are 12 053, which is slightly less than the actual value. This is due to the reason that not all papers could be indexed in WoS.

\section{b) Classification of Collaborating Countries}

To understand and identify the reasons for collaborating Egyptian scientists with their colleagues in 166 countries, these countries could be grouped using three different approaches according to the geographic position, scientific capacities and economic development rate (Figure 4). 


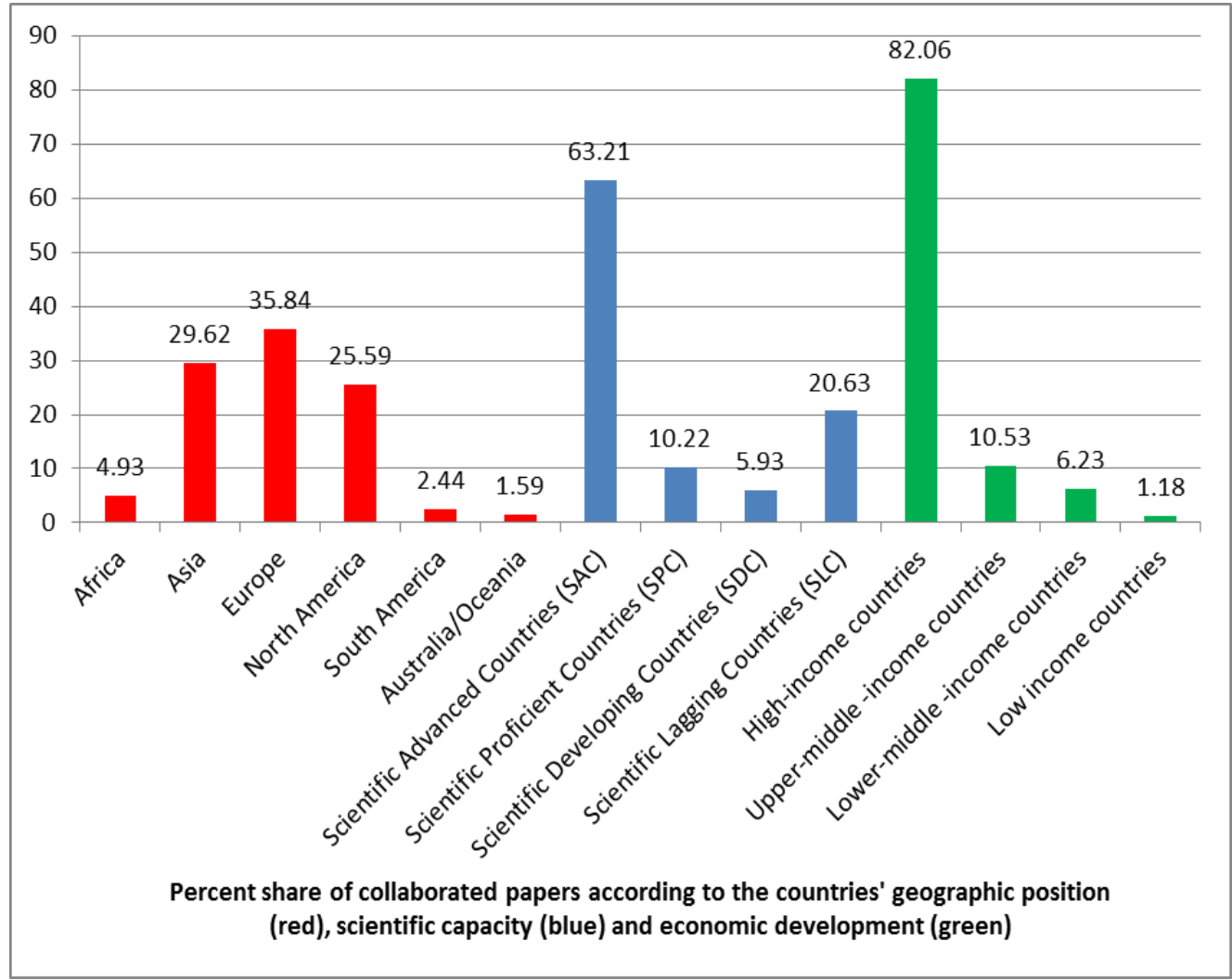

Figure 4: Percent Share of Collaborated Papers according to the Countries' Geographic Position (red), Scientific Capacity (blue) and Economic Development (green)

\section{Countries according to geographic position}

The 166 collaborating countries with Egyptian researchers in health sciences were grouped into six subgroups, i.e., Africa, Asia, Europe, North America, South America, and Australia/Oceanian. The number of co-authored articles of each continent with Egypt are calculated and depicted in Figure 4. The results revealed that Egyptian scientists collaborated mostly with their colleagues in the following order: Europe $(35.84 \%)>$ Asia $(29.62 \%)>$ North America (25.59\%) > Africa (4.93\%) > South America (2.44\%) > Australia/Oceania (1.59\%).

\section{Countries according to scientific capacity}

Wagner et al. (2001) proposed a composite S\&T capacity index using seven indicators of S\&T investment, infrastructure and output. These indicators measure the capacity of a country to conduct scientific research. The indicators include per capita gross national product (GNP); number of scientists and engineers per million people; number of S\&T journal articles / patents; R\&D expenditure (\% of GNP); number of universities and research institutions per million people; number of nation's students studying in USA, and number of patents. They used the capacity index value to rank and group 150 countries into four classes of S\&T capacity namely Scientifically Advanced Countries (SAC), Scientifically Proficient Countries (SPC), Scientifically Developing Countries (SDC), and Scientifically Lagging Countries (SLC). Based on this index, the number of countries in each group is as follows: $22,24,24$ and 80 for SAC, SPC, SDC and SLC, respectively.

The main partners of Egyptian scientists were SAC (63.21\%). The second, third and fourth partner groups were, SLC (20.63\%), SPC (10.22\%) and SDC (5.93\%), respectively (Figure 4). 
It is obvious that scientifically advanced countries motivated Egyptian researchers to collaborate. This finding is in accordance with that was observed by Gazni, Sugimoto and Didegah (2012). It indicates that the international collaboration of Egyptian scientists is affected by the scientific capacity of the collaborating country.

Table 5: Top 20 Collaborating Countries with Egypt over the Period 1980 - 2014

\begin{tabular}{|c|c|c|c|c|c|}
\hline Name & $\begin{array}{c}\text { Collaborated } \\
\text { papers }\end{array}$ & $\begin{array}{c}\% \text { of total } \\
\text { international } \\
\text { collaboration }\end{array}$ & $\begin{array}{l}\% \text { of total } \\
\text { Egyptian } \\
\text { output* }\end{array}$ & $\begin{array}{l}\text { Citation } \\
\text { Impact }\end{array}$ & $\begin{array}{l}\text { Top collaborating discipline } \\
\text { (papers) }{ }^{* *}\end{array}$ \\
\hline & & & & & Public, Environmental \& \\
\hline USA & 4426 & 36.92 & 14.18 & 13.87 & Occupational Health (599) \\
\hline Saudi Arabia & 1907 & 15.91 & 6.11 & 5.27 & $\begin{array}{l}\text { Pharmacology \& Pharmacy } \\
\text { (543) }\end{array}$ \\
\hline Germany & 1321 & 11.02 & 4.23 & 13.89 & $\begin{array}{l}\text { Pharmacology \& Pharmacy } \\
\text { (347) }\end{array}$ \\
\hline England & 1301 & 10.85 & 4.17 & 13.75 & Oncology (153) \\
\hline Japan & 822 & 6.86 & 2.63 & 11.24 & $\begin{array}{l}\text { Pharmacology \& Pharmacy } \\
\text { (244) }\end{array}$ \\
\hline Italy & 624 & 5.21 & 2.00 & 16.18 & Oncology (77) \\
\hline Canada & 578 & 4.82 & 1.85 & 12.87 & $\begin{array}{l}\text { Urology \& Nephrology (85) } \\
\text { Gastroenterology \& }\end{array}$ \\
\hline France & 567 & 4.73 & 1.82 & 13.2 & $\begin{array}{l}\text { Hepatology ( } 88) \\
\text { Cardiac \& Cardiovascular }\end{array}$ \\
\hline Netherlands & 483 & 4.03 & 1.55 & 17.75 & $\begin{array}{l}\text { Systems (77) } \\
\text { Public, Environmental \& }\end{array}$ \\
\hline Switzerland & 472 & 3.94 & 1.51 & 21.29 & Occupational Health (82) \\
\hline Spain & 307 & 2.56 & 0.98 & 21.42 & Ophthalmology (77) \\
\hline Belgium & 261 & 2.18 & 0.84 & 23.74 & $\begin{array}{l}\text { Oncology (64) } \\
\text { Public, Environmental \& }\end{array}$ \\
\hline India & 258 & 2.15 & 0.83 & 15.55 & Occupational Health (39) \\
\hline Australia & 242 & 2.02 & 0.78 & 22.1 & Psychiatry (23) \\
\hline & & & & & Pharmacology \& Pharmacy \\
\hline China & 241 & 2.01 & 0.77 & 17.83 & (34) \\
\hline Turkey & 239 & 1.99 & 0.77 & 12.05 & Hematology (32) \\
\hline Kuwait & 212 & 1.77 & 0.68 & 6.57 & $\begin{array}{l}\text { Pharmacology \& Pharmacy } \\
\text { (24) }\end{array}$ \\
\hline Brazil & 210 & 1.75 & 0.67 & 17.12 & Obstetrics \& Gynecology (23) \\
\hline Lebanon & 209 & 1.74 & 0.67 & 9.32 & Hematology (62) \\
\hline Sweden & 189 & 1.58 & 0.61 & 25.94 & Oncology (29) \\
\hline
\end{tabular}

*The sum is not $100 \%$, a paper may be counted in various countries

**According to Web of Science schema

\section{Countries according to economic development rate}

Based on the economic development rate, countries were classified by the World Bank (2015) into four groups namely: high income, upper middle income, lower middle income and low income. As shown in Figure 4, the most collaborating countries were high income countries $(82.06 \%)$, followed by upper middle income $(10.53 \%)$, lower middle income (6.23\%), and low-income countries (1.18\%). This shows that economic development rate is a plausible explanation for the international scientific collaboration of Egyptian scientists.

\section{Top collaborating countries}

The total number of Egyptian international co-authored papers is 12053 accounting for 38.41 percent of total Egypt research papers in clinical, pre-clinical and health. As Table 5 shows, the USA has collaborated with Egyptian authors in 4426 papers, accounting for 36.92 percent of all 12053 records. Saudi Arabia ranks second with 1907 papers (15.91\%). Germany, England and Japan have respectively 1321, 1301 and 822 papers co-authored with Egypt (11.02\%, $10.85 \%$ and $6.86 \%$, respectively). The top five countries (USA, Saudi Arabia, Germany, England and Japan) have together 9777 co-authored papers with Egyptian scientists (80.36\%). It reveals that nearly 80 percent of the Egyptian co-authored 
articles in health sciences are collaborated with these five countries, and more than one third (36.92\%) are with the United States. The unique economic, scientific and cultural potential and facilities of the USA attracted the Egyptian researchers, as in the other developing countries, to collaborate with the USA researchers.

Although collaboration with the USA and Saudi Arabia yielded the largest number of papers (4426 and 1907, respectively), the highest citation impacts came from Sweden, Belgium, Australia, Spain, and Switzerland (25.94, 23.74, 22.10, 21.42 and 21.29, respectively). Collaboration with developed countries leads to publications with high citation impact (Figure 5). Moreover, citation impact of the collaboration publications with developed countries is higher than the average world citation impact (12.95). Whereas collaboration with three Arab countries (Saudi Arabia, Kuwait and Lebanon) in the top 20 collaborating countries lead to publications with low citation impact $(5.27,6.57$ and 9.32, respectively) and less than the average world citation impact (12.95).

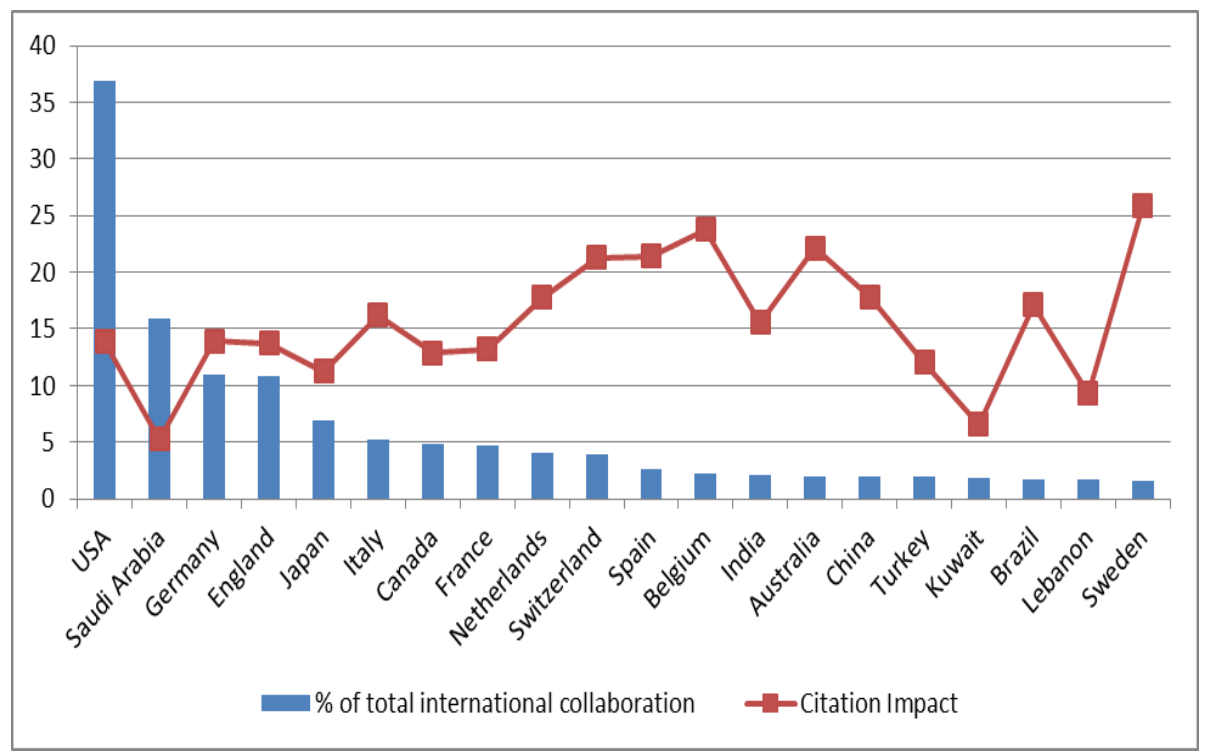

Figure 5: Percentage of International Collaboration and Citation Impact of with the Top 20 Countries

\section{Institutional Analysis}

\section{a) Most Collaborative National Institutions}

Of the total 12053 internationally co-authored articles with Egyptian researchers, Cairo, Ain Shams, Alexandria, Mansoura, and Assiut universities are the five top Egyptian universities that have the most records of international co-authored papers $(2508,1402$, 1352, 1022, and 1265, accounting for 20.81 percent, 11.63 percent, 11.22 percent, 8.48 percent and 10.50 percent of the Egyptian collaboration in health sciences, respectively). These five universities have together contributed 7549 co-authored papers with international colleagues accounting for $62.63 \%$ of the total international papers. This is not surprising because these universities are among the six oldest universities in Egypt as well as the most productive universities in clinical, pre-clinical and health research or in overall research (all subject fields) as can be seen in Table 6. Since Cairo University is the leading, largest and the oldest university in Egypt, it is not surprising that it accounts for a significant portion of publications. Cairo University produced 7273 papers equivalent to 
23.18 percent of the total Egypt in clinical, pre-clinical and health. Again, the co-authorship ratio is $\geq 89 \%$ for the top five Egyptian universities. Also, the citation impact and h-index for multi-author papers are higher than that of single author papers for all the top five Egyptian universities

Table 6: Top 5 Most Prolific Egyptian Universities and their Collaborative Patterns in Health Sciences over the Period 1980-2014

\begin{tabular}{|c|c|c|c|c|c|}
\hline \multirow[t]{2}{*}{ Indicator } & \multicolumn{5}{|c|}{ University } \\
\hline & Cairo & Ain Shams & Alexandria & Mansoura & Assiut \\
\hline Web of Science papers & 23394 & 14305 & 12479 & 10242 & 12136 \\
\hline (\% of total Egypt, 125938) & $(18.58 \%)$ & $(11.36 \%)$ & (9.91\%) & $(8.13 \%)$ & (9.64\%) \\
\hline \multicolumn{6}{|l|}{ Papers in GIPP clinical, pre-clinical and health } \\
\hline \multirow[t]{2}{*}{ Overall (\% of total University) } & 7279 & 3987 & 3891 & 3402 & 2920 \\
\hline & $(31.11 \%)$ & $(27.87 \%)$ & (31.18\%) & $(33.22 \%)$ & $(24.06)$ \\
\hline \multirow[t]{2}{*}{ Single authors (\%) } & 764 & 382 & 429 & 304 & 320 \\
\hline & $(10.50 \%)$ & $(9.58 \%)$ & $(11.03 \%)$ & $(8.94 \%)$ & $(10.96 \%)$ \\
\hline \multirow[t]{2}{*}{ Multi-authors (\%) } & 6515 & 3605 & 3462 & 3098 & 2600 \\
\hline & $(89.50 \%)$ & $(90.42 \%)$ & $(88.97 \%)$ & (91.04\%) & (89.04\%) \\
\hline International papers & 2508 & 1402 & 1352 & 1022 & 1265 \\
\hline$\%$ share in Egyptian international papers & $20.81 \%$ & $11.63 \%$ & $11.21 \%$ & $8.48 \%$ & $10.50 \%$ \\
\hline \multicolumn{6}{|l|}{$(12053)$} \\
\hline \multicolumn{6}{|l|}{ Citation impact } \\
\hline Overall & 7.29 & 7.53 & 7.75 & 7.61 & 7.94 \\
\hline Single author papers & 6.18 & 4.55 & 7.59 & 5.11 & 7.58 \\
\hline Multi-author papers & 7.63 & 8.07 & 7.95 & 8.06 & 8.20 \\
\hline \multicolumn{6}{|l|}{ h-Index } \\
\hline Overall & 72 & 64 & 61 & 53 & 52 \\
\hline Single author papers & 31 & 21 & 25 & 19 & 22 \\
\hline Multi-author papers & 72 & 65 & 61 & 52 & 51 \\
\hline
\end{tabular}

\section{b) Most Collaborative International Institutions}

Table 7 shows the top 20 collaborating international institutions with Egyptian researchers comprising 39.67 percent (4782 out of 12053) of the total Egyptian collaboration papers in clinical, pre-clinical and health. It is found that King Saud University, KSA was the most frequent collaborator with 524 publications $(4.37 \%$ of the total Egypt international collaboration). 50 percent (10 Universities) of the Egypt's top collaborating institutions are from USA. Also, three institutions (15\%) from both England and Saudi Arabia and only one institution from four other countries (France, Canada, Germany and Switzerland) are among the top collaborating institutions, i.e., USA (10), England (3) and Saudi Arabia (3) The highest citation impacts $(24.13,19.90,19.29,19.00,18.55,18.46,18.35,18.11,17.79$ and 17.61) were observed for papers co-authored with World Health Organization, Netherlands; National Institute of Health, USA; University of Maryland Baltimore, USA; Centers for Disease Control \& Prevention, USA; Harvard University, USA; Johns Hopkins, USA; University System of Maryland, USA; US Department of Defense, USA; Imperial College London, England; and University of London, England, although they ranked the positions $10,12,9,15,14,13,8,2,19$ and 5 , respectively, by productivity of collaboration publications with Egyptian researchers. 
Table 7: Top 20 International Collaborating Organizations with Egypt over the Period $1980-2014$

\begin{tabular}{|c|c|c|c|c|c|c|c|}
\hline Rank & Organization & Country & $\begin{array}{c}\text { Collaborated } \\
\text { papers }\end{array}$ & $\begin{array}{c}\% \text { of total } \\
\text { international } \\
\text { collaboration }\end{array}$ & $\begin{array}{c}\text { \% of total } \\
\text { Egyptian } \\
\text { outpour }\end{array}$ & $\begin{array}{l}\text { Citation } \\
\text { Impact }\end{array}$ & $\begin{array}{l}\text { Top collaborating discipline } \\
\text { (papers) }\end{array}$ \\
\hline 1 & King Saud University & $\begin{array}{l}\text { Saudi } \\
\text { Arabia }\end{array}$ & 524 & 4.37 & 1.68 & 5.62 & $\begin{array}{l}\text { Pharmacology \& Pharmacy } \\
\text { (233) }\end{array}$ \\
\hline 2 & United States Department of Defense & USA & 409 & 3.41 & 1.31 & 18.11 & $\begin{array}{l}\text { Public, Environmental \& } \\
\text { Occupational Health (196) }\end{array}$ \\
\hline 3 & King Abdulaziz University & $\begin{array}{l}\text { Saudi } \\
\text { Arabia }\end{array}$ & 370 & 3.09 & 1.19 & 3.85 & $\begin{array}{l}\text { Pharmacology \& Pharmacy } \\
\text { (141) }\end{array}$ \\
\hline 4 & University of London & England & 354 & 2.95 & 1.13 & 17.15 & Oncology (42) \\
\hline 5 & United States Navy & USA & 351 & 2.93 & 1.12 & 17.61 & $\begin{array}{l}\text { Public, Environmental \& } \\
\text { Occupational Health (179) }\end{array}$ \\
\hline 6 & $\begin{array}{l}\text { Centre National de la Recherche } \\
\text { Scientifique (CNRS) }\end{array}$ & France & 304 & 2.54 & 0.97 & 11.96 & $\begin{array}{l}\text { Gastroenterology \& } \\
\text { Hepatology (72) }\end{array}$ \\
\hline 7 & University of California System & USA & 273 & 2.28 & 0.87 & 15.39 & $\begin{array}{l}\text { Public, Environmental \& } \\
\text { Occupational Health (36) }\end{array}$ \\
\hline 8 & University System of Maryland & USA & 229 & 1.91 & 0.73 & 18.35 & $\begin{array}{l}\text { Public, Environmental \& } \\
\text { Occupational Health (85) }\end{array}$ \\
\hline 9 & University of Maryland Baltimore & USA & 205 & 1.71 & 0.66 & 19.29 & $\begin{array}{l}\text { Public, Environmental \& } \\
\text { Occupational Health (80) }\end{array}$ \\
\hline 10 & World Health Organization & Switzerland & 198 & 1.65 & 0.63 & 24.13 & $\begin{array}{l}\text { Public, Environmental \& } \\
\text { Occupational Health (74) }\end{array}$ \\
\hline 11 & University College London & England & 196 & 1.64 & 0.63 & 14.29 & Hematology (34) \\
\hline 12 & National Institutes of Health $(\mathrm{NIH})$ & USA & 186 & 1.55 & 0.60 & 19.90 & Oncology (45) \\
\hline 13 & Johns Hopkins University & USA & 184 & 1.53 & 0.59 & 18.46 & $\begin{array}{l}\text { Public, Environmental \& } \\
\text { Occupational Health (41) }\end{array}$ \\
\hline 14 & Harvard University & USA & 176 & 1.47 & 0.56 & 18.55 & $\begin{array}{l}\text { Gastroenterology \& } \\
\text { Hepatology (32) }\end{array}$ \\
\hline 15 & $\begin{array}{l}\text { Centers for Disease Control \& } \\
\text { Prevention }\end{array}$ & USA & 156 & 1.30 & 0.50 & 19.00 & Infectious diseases (69) \\
\hline 16 & Cleveland Clinic Foundation & USA & 147 & 1.23 & 0.47 & 11.24 & $\begin{array}{l}\text { Obstetrics \& Gynecology } \\
\text { (72) }\end{array}$ \\
\hline 17 & Ruprecht Karl University Heidelberg & Germany & 136 & 1.13 & 0.44 & 14.68 & Oncology (48) \\
\hline 18 & $\begin{array}{l}\text { King Faisal Specialist Hospital \& } \\
\text { Research Center }\end{array}$ & $\begin{array}{l}\text { Saudi } \\
\text { Arabia }\end{array}$ & 130 & 1.08 & 0.42 & 5.53 & Oncology (24) \\
\hline 19 & Imperial College London & England & 128 & 1.07 & 0.41 & 17.79 & $\begin{array}{l}\text { Cardiac \& Cardiovascular } \\
\text { Systems (31) }\end{array}$ \\
\hline 20 & University of Toronto & Canada & 126 & 1.05 & 0.40 & 9.52 & $\begin{array}{l}\text { Dentistry, Oral Surgery \& } \\
\text { Medicine }(20)\end{array}$ \\
\hline
\end{tabular}

\section{Journals Publishing Collaborated and Non-collaborated Papers}

Table 8 shows the top 20 journals (by volume) of the total 1064 journals that published collaborated papers of Egyptian researchers. Articles published in the top 20 journals made 14.75 percent (4629) of the total of journal articles used in this study (3 1382). Articles published in the top 20 journals covered 38.62 percent of the total internationally collaborated articles (11987). Seven journals from USA and 13 were from Europe. The Impact Factor of the top 20 journals varied from 0.672 to 15.203 . Of the top 20 journals, more than half (11) are in the first quartile (Q1) by Journal Impact Factor (i.e., the top 55\% of journals in their subject categories). The other nine journals of the top 20 are distributed among various Quartiles as follows: two in Q1, five in Q3, and two in Q4. The highest number of co-authored papers (484) appeared in Pharmazi (JIF $=1.052, \mathrm{Q} 4)$. The journal with the highest impact of the top 20 is European Heart Journal (JIF $=15.203$, Q1) in which Egyptian researchers published 192 co-authored papers. These findings indicate that there was a tendency for Egyptian researchers to publish most of their publications in the USA and Europe (both 20 out of the top 20 journals). 
Table 8: Top 20 Journals that Published Collaborated Papers

\begin{tabular}{|c|c|c|c|c|c|c|c|}
\hline Rank & Journal & Country & $\begin{array}{c}\text { Collaborated } \\
\text { papers }\end{array}$ & $\begin{array}{l}\text { Journal } \\
\text { Impact } \\
\text { Factor* }\end{array}$ & Category* & Quartile* & Rank* \\
\hline 1 & Pharmazie & Germany & 484 & 1.052 & $\begin{array}{c}\text { Pharmacology \& } \\
\text { Pharmacy }\end{array}$ & Q4 & $214 / 254$ \\
\hline 2 & Fertility and Sterility & USA & 351 & 4.590 & $\begin{array}{l}\text { Obstetrics \& } \\
\text { Gynecology }\end{array}$ & Q1 & $4 / 79$ \\
\hline 3 & Planta Medica & Germany & 330 & 2.152 & $\begin{array}{c}\text { Pharmacology \& } \\
\text { Pharmacy }\end{array}$ & Q3 & $137 / 254$ \\
\hline 4 & $\begin{array}{l}\text { American Journal of } \\
\text { Tropical Medicine and } \\
\text { Hygiene }\end{array}$ & USA & 320 & 2.699 & Tropical Medicine & Q1 & $3 / 19$ \\
\hline 5 & Hepatology & USA & 301 & 11.055 & $\begin{array}{c}\text { Gastroenterology \& } \\
\text { Hepatology }\end{array}$ & Q1 & $5 / 76$ \\
\hline 6 & Archiv Der Pharmazie & Germany & 241 & 1.531 & $\begin{array}{c}\text { Pharmacology \& } \\
\text { Pharmacy }\end{array}$ & Q3 & $179 / 254$ \\
\hline 7 & $\begin{array}{l}\text { Journal of } \\
\text { Pharmaceutical and } \\
\text { Biomedical Analysis }\end{array}$ & Netherlands & 241 & 2.979 & $\begin{array}{c}\text { Pharmacology \& } \\
\text { Pharmacy }\end{array}$ & Q2 & $81 / 254$ \\
\hline 8 & Journal of Urology & USA & 234 & 4.471 & $\begin{array}{c}\text { Urology \& } \\
\text { Nephrology }\end{array}$ & Q1 & $9 / 76$ \\
\hline 9 & Food Chemistry & England & 215 & 3.391 & Nutrition \& Dietetics & Q1 & 19/77 \\
\hline 10 & Human Reproduction & England & 204 & 4.569 & $\begin{array}{l}\text { Obstetrics \& } \\
\text { Gynecology }\end{array}$ & Q1 & $5 / 79$ \\
\hline 11 & European Heart Journal & England & 192 & 15.203 & $\begin{array}{c}\text { Cardiac \& } \\
\text { Cardiovascular } \\
\text { Systems }\end{array}$ & Q1 & $3 / 123$ \\
\hline 12 & Journal of Hepatology & Netherlands & 187 & 11.336 & $\begin{array}{c}\text { Gastroenterology \& } \\
\text { Hepatology }\end{array}$ & Q1 & $4 / 76$ \\
\hline 13 & Urology & USA & 184 & 2.188 & $\begin{array}{c}\text { Urology \& } \\
\text { Nephrology }\end{array}$ & Q2 & $28 / 76$ \\
\hline 14 & Liver International & Denmark & 180 & 4.850 & $\begin{array}{c}\text { Gastroenterology \& } \\
\text { Hepatology }\end{array}$ & Q1 & $13 / 76$ \\
\hline 15 & $\begin{array}{l}\text { International Journal of } \\
\text { Gynecology \& } \\
\text { Obstetrics }\end{array}$ & Netherlands & 178 & 1.537 & $\begin{array}{l}\text { Obstetrics \& } \\
\text { Gynecology }\end{array}$ & Q3 & $51 / 79$ \\
\hline 16 & $\begin{array}{l}\text { International Journal of } \\
\text { Pharmaceutics }\end{array}$ & Netherlands & 174 & 3.650 & $\begin{array}{c}\text { Pharmacology \& } \\
\text { Pharmacy }\end{array}$ & Q1 & $54 / 254$ \\
\hline 17 & $\begin{array}{l}\text { Drug Development and } \\
\text { Industrial Pharmacy }\end{array}$ & USA & 164 & 2.101 & $\begin{array}{c}\text { Pharmacology \& } \\
\text { Pharmacy }\end{array}$ & Q3 & $141 / 254$ \\
\hline 18 & $\begin{array}{l}\text { Applied Radiation and } \\
\text { Isotopes }\end{array}$ & USA & 158 & 1.231 & $\begin{array}{l}\text { Radiology, Nuclear } \\
\text { Medicine \& Medical } \\
\text { Imaging }\end{array}$ & Q3 & $90 / 125$ \\
\hline 19 & Annals of Oncology & England & 147 & 7.040 & Oncology & Q1 & $18 / 211$ \\
\hline 20 & $\begin{array}{l}\text { Journal of Laryngology } \\
\text { and Otology }\end{array}$ & England & 144 & 0.672 & Otorhinolaryngology & Q4 & $38 / 43$ \\
\hline
\end{tabular}

On the other hand, analysis of the top 20 journals (by volume) that published single authored papers of Egyptian researchers (Table 9 ) confirmed the following:

i. Articles published in the top 20 journals comprised 2.4 percent (756) of the total journal articles used in this study (31382).

ii. Articles published in the top 20 journals comprised 20.51 percent (756) of the total single authored articles used in this study (3686).

iii. Out of the 20 journals seven journals are from USA, 12 from Europe, and one from Saudi Arabia.

iv. The Impact Factor of the top journals varied from 0.588 to 13.938 .

v. Of the top 20 journals nine are in the first quartile (Q1), three in Q2, five in Q3 and three in Q4, by Journal Impact Factor.

vi. The highest number of single authored papers (73) appeared in Journal of Urology $(\mathrm{JIF}=4.471, \mathrm{Q} 1)$. 
vii. The journal with the highest impact of the top 20 is European Urology (JIF = 13.938, Q1) in which Egyptian researchers published 19 single authored papers.

In comparing all indicators for collaborated and non-collaborated articles (Tables 8 and 9), one can see that the collaborated papers are better in both quantity and quality. These findings reveal that collaborations enhance both the research output and quality, as well as increase both the opportunity to publish in international journals with high impact factor and the number of journals in the first quartile (Q1) (11 out of the top 20 are Q1 for collaborated papers, whereas single papers are published in only nine Q1 journals).

Table 9: Top 20 Journals that Published Non-collaborated Papers

\begin{tabular}{|c|c|c|c|c|c|c|c|}
\hline Rank & Journal & Country & Papers & $\begin{array}{l}\text { Journal } \\
\text { Impact } \\
\text { Factor* }\end{array}$ & Category* & Quartile* & Rank* \\
\hline 1 & Journal of Urology & USA & 73 & 4.471 & Urology \& Nephrology & Q1 & $9 / 76$ \\
\hline 2 & Pharmazie & Germany & 73 & 1.052 & $\begin{array}{c}\text { Pharmacology \& } \\
\text { Pharmacy }\end{array}$ & Q4 & $214 / 254$ \\
\hline 3 & Food Chemistry & England & 64 & 3.391 & Nutrition \& Dietetics & Q1 & 19/77 \\
\hline 4 & Urology & USA & 60 & 2.188 & Urology \& Nephrology & Q2 & $28 / 76$ \\
\hline 5 & Journal of Sexual Medicine & USA & 54 & 3.151 & Urology \& Nephrology & Q1 & $17 / 76$ \\
\hline 6 & $\begin{array}{l}\text { Applied Radiation and } \\
\text { Isotopes }\end{array}$ & USA & 49 & 1.231 & $\begin{array}{l}\text { Radiology, Nuclear } \\
\text { Medicine \& Medical } \\
\text { Imaging }\end{array}$ & Q3 & $90 / 125$ \\
\hline 7 & $\begin{array}{l}\text { Journal of Pharmaceutical } \\
\text { and Biomedical Analysis }\end{array}$ & Netherlands & 49 & 2.979 & $\begin{array}{c}\text { Pharmacology \& } \\
\text { Pharmacy }\end{array}$ & Q2 & $81 / 254$ \\
\hline 8 & $\begin{array}{l}\text { Journal of Laryngology and } \\
\text { Otology }\end{array}$ & England & 41 & 0.672 & Otorhinolaryngology & Q4 & $38 / 43$ \\
\hline 9 & Fertility and Sterility & USA & 39 & 4.590 & $\begin{array}{l}\text { Obstetrics \& } \\
\text { Gynecology }\end{array}$ & Q1 & $4 / 79$ \\
\hline 10 & $\begin{array}{l}\text { International Journal of } \\
\text { Gynecology \& Obstetrics }\end{array}$ & Netherlands & 30 & 1.537 & $\begin{array}{l}\text { Obstetrics \& } \\
\text { Gynecology }\end{array}$ & Q3 & $51 / 79$ \\
\hline 11 & BJU International & England & 28 & 3.533 & Urology \& Nephrology & Q1 & $13 / 76$ \\
\hline 12 & $\begin{array}{l}\text { Plastic and Reconstructive } \\
\text { Surgery }\end{array}$ & USA & 27 & 2.993 & Surgery & Q1 & $36 / 198$ \\
\hline 13 & Planta Medica & Germany & 26 & 2.152 & $\begin{array}{l}\text { Pharmacology \& } \\
\text { Pharmacy }\end{array}$ & Q3 & $137 / 254$ \\
\hline 14 & Liver International & Denmark & 22 & 4.850 & $\begin{array}{c}\text { Gastroenterology \& } \\
\text { Hepatology }\end{array}$ & Q1 & $13 / 76$ \\
\hline 15 & Saudi Medical Journal & Saudi Arabia & 22 & 0.588 & $\begin{array}{l}\text { Medicine, General \& } \\
\text { Internal }\end{array}$ & Q4 & $117 / 153$ \\
\hline 16 & Archiv Der Pharmazie & Germany & 21 & 1.531 & $\begin{array}{c}\text { Pharmacology \& } \\
\text { Pharmacy }\end{array}$ & Q3 & $179 / 254$ \\
\hline 17 & Human Reproduction & England & 20 & 4.569 & $\begin{array}{l}\text { Obstetrics \& } \\
\text { Gynecology }\end{array}$ & Q1 & $5 / 79$ \\
\hline 18 & Vox Sanguinis & England & 20 & 2.799 & Hematology & Q2 & $29 / 68$ \\
\hline 19 & $\begin{array}{l}\text { Drug Development and } \\
\text { Industrial Pharmacy }\end{array}$ & USA & 19 & 2.101 & $\begin{array}{c}\text { Pharmacology \& } \\
\text { Pharmacy }\end{array}$ & Q3 & $141 / 254$ \\
\hline 20 & European Urology & Netherlands & 19 & 13.938 & Urology \& Nephrology & Q1 & $1 / 76$ \\
\hline
\end{tabular}

*Journal Citation Reports (2015)

\section{Main Collaborated Research Areas}

As seen in Table 3, the most frequent disciplines in collaboration are Rheumatology (96\%), Infectious diseases (95\%), Tropical medicine (95\%), Immunology (95\%), and Oncology $(94 \%)$, in which $\geq 94 \%$ of their publications are collaborated papers. It means that there is a need for more instruments, ideas, analyses and interpretations in these complex disciplines. These subjects call for more collaborations between researchers with various knowledge, expertise, competencies and labs facilities. Overall, international collaborations are dominant in common problems, i.e., with across-countries interest. 


\section{Prediction of Research Output and Quality (Effect of International Collaboration)}

Figure 6 shows the total publications $(1980-2014)$ and citations $(1980-2011)$ of Egypt clinical, pre-clinical \& health publications plotted versus the number of international collaborations. There is a constant increase in the value of total publications or citations with the number of Egyptian international collaborations (IC). Therefore, one can accurately estimate (forecast) the expected Egyptian publications and citations for the next years using the following two equations:

Total Egyptian publications $(1980-2014)=97.828+2.3602 \mathrm{IC}\left(\mathrm{R}^{2}=0.9958\right)$

Total citations $(1980-2008)=1119.2+26.058 I C\left(R^{2}=0.8695\right)$

The correlations are very strong $\left(R^{2}=0.9958\right.$ and $R^{2}=0.8695$ for publications and citations, respectively), especially in the case of total publications, suggesting that international coauthorship is remarkably correlated with the publication output and quality. Based on these results, the contributions of international collaboration to the Egyptian research in health sciences and citations were determined. Thus, the total Egyptian health sciences' publications and citations can be calculated with sufficient accuracy using the derived equations.

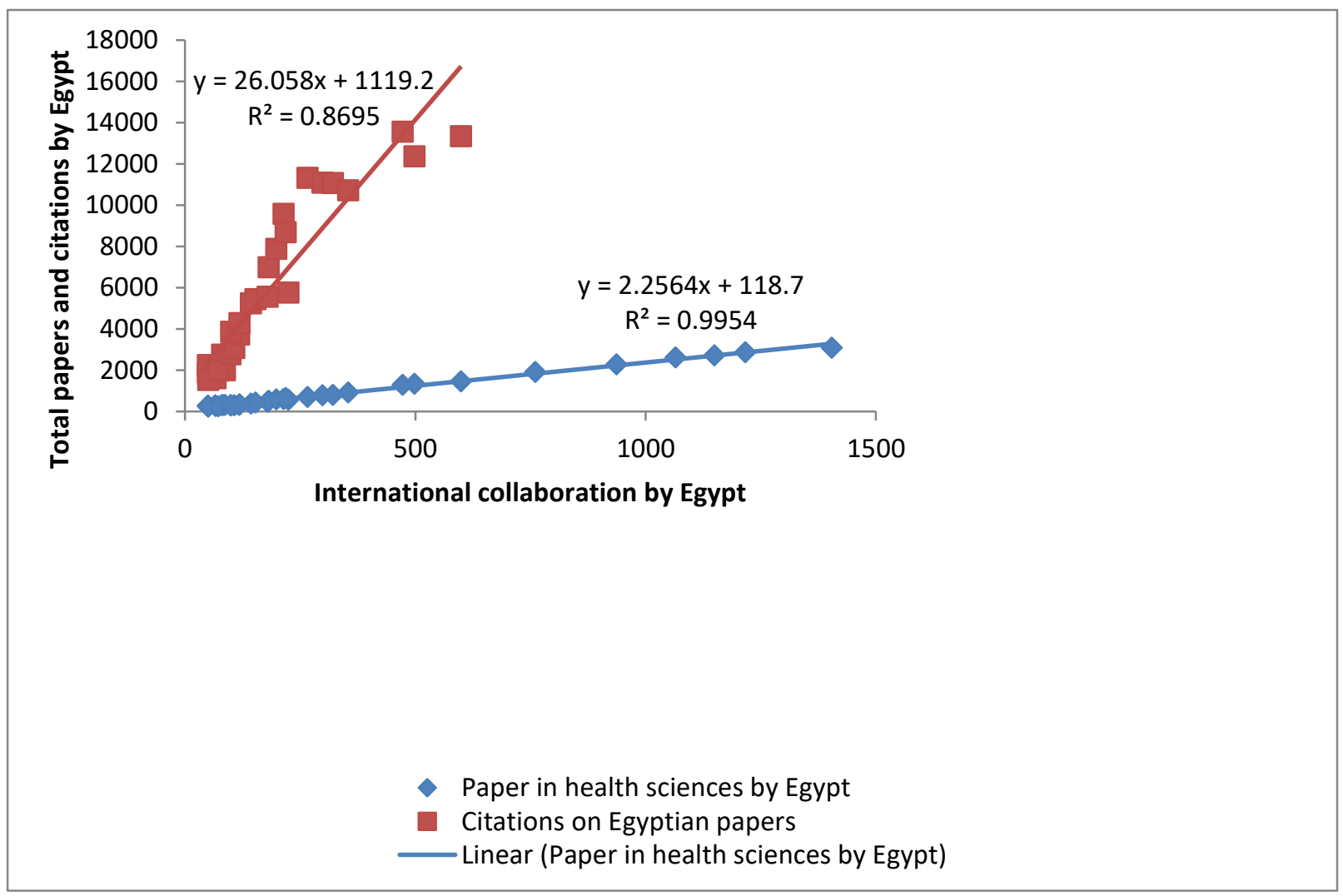

Figure 6. Total Web of Science Documents and Citations Received (1980 - 2011) versus the Number of International Collaborations by Egypt

\section{CONCLUSION}

In this paper, we have used bibliometric analysis of 31382 articles listed in the Thomson Reuters' WoS database. This number is the output of Egyptian researchers in clinical, preclinical \& health field. The results of this study show that the share of single, domestic and 
international collaboration papers is $0.12,0.50$ and 0.38 , respectively, indicating that the co-authorship ratio is 88 percent and Egyptian scientist have a great tendency to collaborate. Moreover, the total citations received by internationally collaborated papers are higher than those citations received by single authors or domestically collaborated papers. Also, the citation impact and h-index increase with the increasing number of authors.

The research activity of Egyptian researchers in clinical, pre-clinical \& health is satisfactory to some extent, but it is still far from the global baseline. The research productivity and outcomes can be improved significantly by implementing a strategy for enhancing research through domestic and international collaborations.

The findings of the present work have many policy implications such as developing national initiatives and programmes for:

i. Promoting national and international collaborations,

ii. Allocating research funds,

iii. Promoting competition in research publications in international journals or in journals indexed in Web of Science and Scopus,

iv. Enhancing facilities and infrastructure necessary for research,

v. Establishing centers of research excellence and science parks (Techno valleys), and

vi. Motivating researchers for scientific achievement and recognition.

\section{ACKNOWLEGEMENT}

This research did not receive any grant from any funding agency in the public, commercial or not-for-profit sector.

\section{REFERENCES}

Aboulghar, M. 2011. Barriers to conducting clinical research in reproductive medicine: Egypt. Fertility and Sterility, Vol. 96, no.4: 805-806.

Abramo, G., D'Angelo, C.A., and Solazzi, M. 2011. The relationship between scientists' research performance and the degree of internationalization of their research. Scientometrics, Vol.86, no.3: 629-643.

Adams, J. 2013. Collaborations: The fourth age of research. Nature, Vol.497, no.7451: 557560.

Adams, J., Black, G., Clemmons, R., and Stephan, P. 2005. Scientific teams and institutional collaborations: Evidence from U.S. universities, 1981-1999. Research Policy, Vol.34, no.3: 259-286.

Adams, J., Gurney, K. C., and Leydesdorff, L. 2014. International collaboration clusters in Africa. Scientometrics, Vol.98, no.1: 547-556.

Afifi, M. 2007. Egyptian biomedical publications in PubMed, 1996 -2005. The Journal of the Egyptian Public Health Association, Vol.82, no.1-2: 91-104.

Ahmed, J., Bouloy, M., Ergonul, O., Fooks, A., Paweska, J., Chevalier, V., Drosten, C., Moormann, R., Tordo, N., Vatansever, Z., Calistri' P., Estrada-Peña, A., Mirazimi, A., Unger, H., Yin, H. and Seitzer, U. 2009. International network for capacity building for the control of emerging viral vector-borne zoonotic diseases: ARBO-ZOONET. Euro Surveill, Vol.14, no.12: 1-4. 
Ardanuy, J. 2012. Scientific collaboration in library and information science viewed through the Web of Knowledge: The Spanish case. Scientometrics, Vol.90, no.3: 877890.

Bordons, M., Aparicio, J., and Costas, R. 2013. Heterogeneity of collaboration and its relationship with research impact in a biomedical field. Scientometrics, Vol.96, no.2: 443-466.

Bornmann, L. and Leydesdorff, L. 2013. Macro-indicators of citation impacts of six prolific countries: InCites data and the statistical significance of trends. PLOS ONE, Vol.8, no.2: e56768.

Chuang, K. Y., Chuang, Y. C., Ho, M., and Ho, Y. S. 2011. Bibliometric analysis of public health research in Africa: The overall trend and regional comparisons. South African Journal of Science, Vol.107, no.5/6: 54-59.

De Filippo, D., Aparicio, J., and Go'mez, I. 2009. Measuring the benefits of International collaboration: A case study of the relationship between Latin-American and European countries. In: B. Larsen and J. Leta, eds. Proceedings of the 12th international conference of the ISSI. Brasil: BIREMEPPAHO/WHO and Federal University of Rio de Janeiro: 920-921.

Durando, P., Sticchi, L., Sasso, L., and Gasparini, R. 2007. Public health research literature on infectious diseases: Coverage and gaps in Europe. European Journal of Public Health, Vol.17, suppl 1: 19-23.

Freshwater, D., Sherwood, G., and Drury, V. 2006. International research collaboration: Issues, benefits and challenges of global network. Journal of Research in Nursing, Vol.11, no.4: 295-303.

Gazni, A. and Didegah, F. 2011. Investigating different types of research collaboration and citation impact: A case study of Harvard University's publications. Scientometrics, Vol.87, no.2: 251-265.

Gazni, A., Sugimoto, C. R., and Didegah, F. 2012. Mapping world scientific collaboration: Authors, institutions and countries. Journal of the American Society for Information Science and Technology, Vol.63, no.2: 323-335.

Ghaleh, N. R., Siadat, F., and Azizi, F. 2004. Quantitative and qualitative assessment of biomedical publications from Iran, Pakistan and Egypt through their impact factor. Journal of Pakistan Medical Association, Vol.54, no.10: 528-9.

Glänzel, W. 2001. National characteristics in international scientific co-authorship relations. Scientometrics, Vol.51, no.1: 69-115.

Glänzel, W. and De Lange, C. 2002. A distributional approach to multi-nationality measures of international scientific collaboration. Scientometrics, Vol.54, no.1: 75-89.

Glänzel, W. and Schubert, A. 2004. Analysing scientific networks through co-authorship. In: $\mathrm{H}$. F. Moed, et al. eds. Handbook of quantitative science and technology research. Dordrecht: Kluwer: 257-276.

Gonzalez-Alcaide, G. 2010. Authorship, collaboration and citation patterns of biomedical journals published in Spain and included in journal citation reports (2003-2007). Revista Espanola De Documentacion Cientifica, Vol.98, no.2: 397-427.

Guerrero-Bote, V. P., Olmeda-Go'mez, C., and Moya-Anego'n, F. 2013. Quantifying the benefits of international scientific collaboration. Journal of the American Society for Information Science and Technology, Vol.64, no.2: 392-404.

Hanna-Mari, P., Muhonen, R., and Leino, Y. 2014. International and domestic co-publishing and their citation impact in different disciplines. Scientometrics, Vol.98, no.2: 823-839.

Helal, R., Abou-ElWafa, H., and El-Gilany, A. 2015. Publication productivity of faculty of medicine, Mansoura University indexed in PubMed. Annals of Medical \& Health Sciences Research, Vol.4, no.3: 278-285. 
InCites $^{\mathrm{TM}}$ Thomson Reuters. 2014. InCites indicator handbook. Available at: http://researchanalytics.thomsonreuters.com/m/pdfs/indicators-handbook.pdf.

Lancho-Barrantes, B., Guerrero-Bote, V., and Moya-Anego'n, F. 2013. Citation increments between collaborating countries. Scientometrics, Vol.94, no.3: 817-831.

Leydesdorff, L., Wagner, C. S., Park, H. W., and Adams, J. 2013. International collaboration in science: The global map and the network. El Profesional de la Informacio'n, Vol.22, no.1: 87-94.

Liu, P., Miu, X. and Xie, H. 2016. China's scientific footprint in the global HIV/AIDS research: Productivity, impact and collaboration. Malaysian Journal of Library \& Information Science, Vol. 21, no. 2: 83-108.

Maghrabi, I. 2013. Review of publication productivity of medicine and pharmacy schools in four Arab universities. Saudi Journal for Health Sciences, Vol.2, no.1: 1-8.

Mostafavi, E. and Bazrafshan, A. 2014. Research and collaboration overview of institute Pasteur international network: A bibliometric approach toward research funding decisions. International Journal of Policy Management, Vol.2, no.1: 21-28.

Patel, V. M., Ashrafian, H., Ahmed, K., Arora, S., Jiwan, S., Nicholson, J. K., Darzi, A. and Athanasiou, T. 2011. How has healthcare research performance been assessed? A systematic review. Journal of the Royal Society of Medicine, Vol.104, no.6: 251-61.

Persson, O., Glänzel, W., and Danell, R. 2004. Inflationary bibliometric values: The role of scientific collaboration and the need for relative indicators in evaluative studies. Scientometrics, Vol.60, no.3: 421-432.

Pouris, A. and Ho, Y. 2014. Research emphasis and collaboration in Africa. Scientometrics, Vol.98, no.3: 2169-2184.

Richet, H. M., Mohammed, J., McDonald, L. C., and Jarvis, W. R. 2001. Building communication networks: International network for the study and prevention of emerging antimicrobial resistance. Emerging Infectious Diseases, Vol.7, no.2: 319-322.

Schmoch, U. and Schubert, T. 2008. Are international co-publications an indicator for quality of scientific research? Scientometrics, Vol.74, no.3: 361-377.

Shrivats, S. V. and Bhattacharya, S. 2014. Forecasting the trend of international scientific collaboration. Scientometrics, Vol.101, no.3: 1941-1954.

Thijs, B. and Glänzel, W. 2010. A structured analysis of collaboration between European research institutes. Research Evaluation, Vol.19, no.1: 55- 65.

Waast, R. and Rossi, P.-L. 2010. Scientific production in Arab countries: A bibliometric perspective. Science Technology and Society, Vol.15, no.2: 339-370.

Wagner, C. S., Brahmakulam, I., Jackson, B., Wong, A., and Yoda, T. 2001. Science and technology collaboration: Building capacities in developing countries. Santa Monica, CA: RAND.

Wagner, C. S. and Leydesdorff, L. 2005. Mapping the network of global science: Comparing international co-authorships from 1990 to 2000. International Journal of Technology and Globalization, Vol.1, no.2: 185-208.

Wang, M. H., Fu, H. Z., and Ho, Y. S. 2011. Comparison of universities' scientific performance using bibliometric indicators. Malaysian Journal of Library \& Information Science, Vol.16, no.2: 1-19.

World Bank. 2015. Country and lending groups. Available at: http://data.worldbank.org/about/country-classifications.

Yu, Q., Shao, H., Long, C., and Duan, Z. 2014. The relationship between research performance and international research collaboration in the $C \& C$ field. Experimental and Clinical Cardiology, Vol.20, no.6: 145-153.

Zeeneldin, A. A., Taha, F. M., and Moneer, M. 2012. Past and future trends in cancer and biomedical research: A comparison between Egypt and the world using PubMedindexed publications. BMC Research Notes, Vol.5, no.1: 349. 